4) The land development in ancient times was selective, and in the Middle Ages the land utilization was made according with physical formation. The development in the Tokugawa-era, however, is getting to urge the slow physical development of plain. This artiflcial urging of development began from about 1750. And at present the inhabitants are reclaiming the foreshore from the sea.

In short, the developments in ancient times and the Middle Ages were passive, leaving itself to circumstances; men were in the situation of being acted upon. In the Tokugawa-era and present times, on the contrary, challenges to the circumstances are being made actively.

Not that the plains keep a record of the victory of man's activities over the physical history. In the Middle Ages, the land system of Jôri type buried in the ground, and breaks of Bandai artificial levees and the other breakwaters shows a case of a temporary defeat of human history in the Tokugawa-era. Even now, shore lines are gradually receding because of erosion. The land depression attributable to earthquakes is increasing the damaged districts from sea-water.

Concerning the study of recent alluvial plains, there is much that requires consideration from various angles in human activities.

\title{
高冷開拓地・八ケ岳山麓野辺山 に水ける集落の変貌
}

小笠 原 節 夫

\section{1 ま え がき}

特に自然条件の制約がない場合，晨業集落の形態は農業生産㥞式に規定され る。したがって農莱生産様式の変化は集落形態に変化をひき起すととが多い。

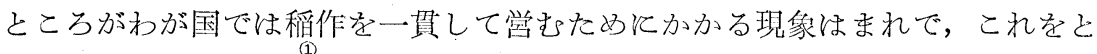
り扱った報告も少ない。との中にあって谷岡武雄氏ほ丹波需原村の土地改底を、 契機とする「集落の二次的分散」，あるいは例を外国飞求めてハンガリ一・アル フェルドに括ける「タンヤ運動」についでニニークな莱績を発表されてきてい

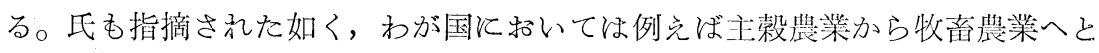
いうような明暸な農業生産様式の変化がそしかったために，これにもとら゙く集 落形態の変化の例をみることがなかった。たかだか從来の経営の集約化，例え ば土地改良などによる集落形態の变化が，それもごくまれにみられたにとど末 る。 
ところが第二次戦後の国民の生活水準のいっそうの向上, 生活様式の変化は 各地にい委だ小規模ながらも酪農地域の形成を促しつつある。一部に農策生産 様式の変草が行われつつあるわけである。このような新しい局面にあたって在 来の農村集落の形態がも乙変化するとすれぼ，いかなる変化を蒙るかは集落地 理学上まこと飞興味ある問題といわなければならない。

一般飞烟作地域は水田地域飞比べて土地生産力が小さく，したがってょり広 い経営地を必要とする。そのため少なくとも個別経営下では前者に括いては農 地への到達度という点で散居を有利とするととは当然である。後者飞招いても 散居が望委しいであろうが，北海道を除くわが国農村の大部分を占める水田地 域の集村は，村落の規模が小さいため耕地への到達度はさして問題にならず， この点の改善という理由だけで早急な集落形態の変化すなわち散村化するとと は今のところ期待されない。

集落形態の変化は集落の移動・消隇とは区別すべきものである。前者は従来： の生活領域内での形態の変化であるのに対して後者は住民が生活領域外へ向っ て永久的飞従前の村落から離脱するとと飞よってひき起される現象だからであ る。

このような意味合いでの集落形態の变化をとり报ったものにはわが国では 綿貫夏彦，小寺廉吉・岸本英夫，谷岡武雄，高田正規諸氏の報告がある。その 他飞竹内常行, 長井政太郎両氏の報告も集落形態の変化の論文として报われる 場合もあるが，これらはいわ散村から集居部が析出したと考兄られるもので あって，住居が移転したことによるものではなく，人口增加によるものである から，本来の集落形態の変化とは区別した方がよい上うである。形態の変化に は散居から集居への変化と，その近の場合とがあるが，綿貫氏は社会生活上の 理由汇よる前者の例を, 小寺・岸本, 高田氏㫟営農上の理由, 谷岡氏は土地改 良を契機とする後者の例をそれぞれ報告された。小寺・岸本，高田氏の示され た例を除いて他の三氏の例は計画的に施行されたものである。

さてここで報告するのは長野県八ケ岳東麓の高冷開拓地「野辺山」に称いて 集村から散村へという集落形態の変化が，従来の蔬菜（大根・甘らん・白菜）の 単一栽培から畜座尊入による混合（同）農業へ々営農方針の転換飞伴って計画 的行われた例である。かかる農業生産様式の变化が進行しつつある地域は現 在わが国の各地飞みられるが，い未だ集落形態の変化を伴った例をきかない。 従ってここで报う例は開発の新しい高冷地という特殊な条件を背負ったきわめ てまれな存在である。しかしたと兄例外的事例であろうとも昨今有畜農業・機 械化農業への転換が話題になっているわが国一般の農村ととって，今後の進む 
ベき—つの方向を示しているかと思うのである。今後の農村の全面的更生は単 なる土地利用の改善にとどまることなく，集落計画をも含めた「羁村計画」の 下に行われるべきであると考光るからである。特に開拓・農栄干拓地怡いて は，從来の伝統といわば断絶しているので農村計画はもっともスムーズに行わ

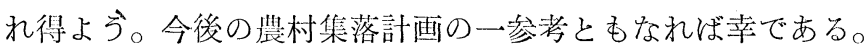

\section{2 地 域 の 概 要}

野辺山開拓地信州八ケ岳の東への緩斜面上，高度 $1,340 \sim 1,380 \mathrm{~m}$ V位置 する。八ケ厚東麓はゆるい起伏をなし，数条の必従谷が東流し，これを千曲川 の支流三沢川が集水して北流する。緩斜面は厚さ $40 \mathrm{~cm}$ 洼どの火山存起源の腐

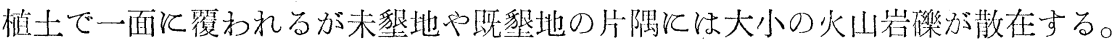
未懇地はささ，すすき，あるいははしばみで㠅わ机ているが，かっては一面に からまつ林であったものが，1943年潼軍砲兵隊演猊場となってから伐採され， 草地と化したものである。

開拓地は海抜 $1,350 \mathrm{~m}$ 前後飞位圆するので父候恬当然冷渲であって，信州大

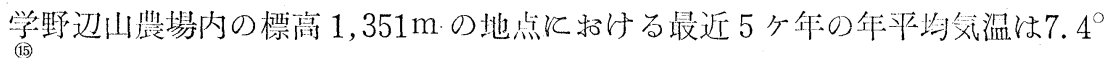

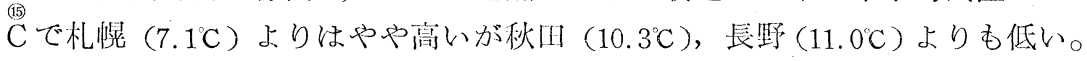
また日最高父温が $20^{\circ} \mathrm{C}$ をえたのは7月から8月にかけての20日内外で, $30^{\circ}$ Cをこ劣たのは最近 5 ケ年に一日もない。一方最低気温はー $20^{\circ} \mathrm{C}$ をること

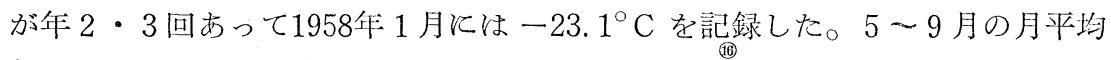
気温が $13^{\circ} \mathrm{C}$ 以上で普通の齒業経営が期待できるがここでは 5 月の平均気温が $10.6^{\circ} \mathrm{C}$ で，当開拓地が耕種䡈業の限界地域であることが察せられる。

年間快啨日数の 5 ケ年平均は78日でとくに夏期に快啨・刞天の日数が多いた め紫外線は低暖地に比して強く, 日射量も多いので気温のわりに地温は高く, 1960年飞は地表温で $20^{\circ} \mathrm{C}$ をこ党た日が7ー9月に38日あった。逆に冬期は， 降雪量が少ないので地洫が低下し，准結がはなはだしい。冬期は西風が強いの で，開拓民は水路にとってからまつを防閩林用飞植林している。

以上のような高冷地としての気候は当地域の農作物の種頪を限定し, 作付讨

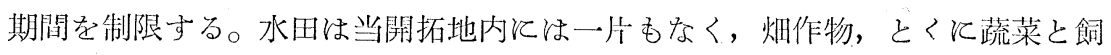
料作物を中心とする土地利用が一面展開されている。

小海線が開拓地のほぼ中央を走り，野辺山駅は1935年飞開設された。バスも 甲府と小諸飞通じて呿り，開拓地としては交通的位置にめぐまれているといっ てよいであろう。ここは八ケ岳登山口の一つであり，夏のキャンプ場にも好邀 なので，士産物店 2 ，旅館 2 があり，閉拓民㳊日常生活品を供給する雑貨店 4 ， その他倉庫，一般住宅あわせて10数戸が駅前に密集してあり，豊機具，肥料の 
販売，貯蓄，営農指導，集会が行われる「農協」とならえで当開拓地のセンタ 一の役目をはたしている。

\section{3 開拓の 沿 革}

符 2 次大艥直後, 食料難と大量の海外からの引揚者炎受け入れ，更に都市羅 災者の都市への復帰が一時的に困難であった状態に括いて食料難の打開とあわ せてこれら困窮をきわ孙国民飞生活の基礎をあた光，失った海外植民地を国 内で補うべく1945年11月「緊急開拓事業」が目諭まれた。これは準備不足とそ の後の経減状势の変化飞よって，初期の計画通りに惟抄しなかったが，八ケ 岳山麓の念場原, 南原山, 野辺山に招ける本格的な開拓はこれと始まり, 現在 一応の成功をみているといってよいであろう。

野辺山開拓の発端は1935年小海線の開通，野辺山駅の開設がきっかけとなっ た。1939年三井財団飞よって大滝農場 (第1図) 約 $40 \mathrm{ha}$ が森林の伐採・抜根

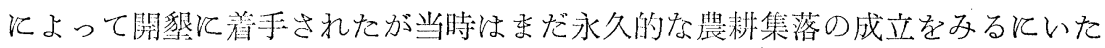
らず，炕代伐採人，炭燃き人小屋が野辺山駅前にあったとすぎない。1943年陸 軍が演習場として当地を接収するに执よてで開拓は中絶した。接収にさいして 旧国有林については間題がなかったが，現開拓地南部と駅前の北東一南西にの びる狭長な入会地の幏収にあたっては接収解除後入会部落に返却する旨の契約 そ行って特り，また文部省用地（その南部が現信州大学野辺山農場）は接収されな かった。当時は先の大滰贯場を除いては一面のからまつ林であったあのを兵隊 拉よび付近の住民を使用して伐採泟たらせた。

戦後この軍州地 $712 \mathrm{ha}$ は最地開発営団, 東京農地事務局をへて長野県が開 拓を代行することになって今日に及んでいる。入植が始まったのは1946年農地 開発営団の管轄下の時期で，入植者は游外引揚者（旧满州開拓民と台湾裴糖会社社 員)，陸軍現地除隊者が大部分をしめ，他飞付近農村の二・三男を含めた百十 数戸で，とりあ兄ず旧陸軍の兵舎飞雑居していたが，彼等は入植と同時にそれ ぞれの出自によって組合をつくり，これを単位として土地の仮配分を受け開笮 飞着手した。組合は 7 個（後8個と增加）あって土地の配分について相互に対立

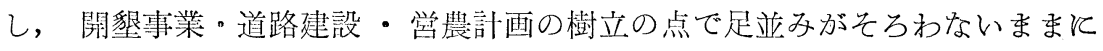
1948年初めに兵舎を解体して各戸飞配分し，入植者は属与る組合の土地の中に 組合単位に住居を建設した。北・東辺部の 2 グループを除いて他は密集してい るのは電登導入の費用の節約のためであり，駅付近飞集っているのが多いのは 交通の便からである。

8 小組合は1948年旧文部省用地の北部々第 1 図中の「地区外」とを交換し， 前者の解放を受けるため大同団結する必要があり，折しも農業協同組合法の施 


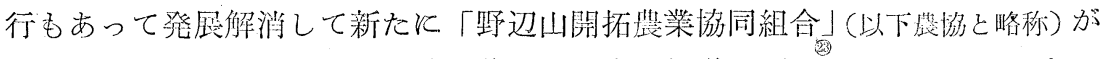
設立され，以後開拓民は同農協の強力な統率と指您の下飞执かれるとになっ たのである。

\section{4 分散前の集落と耕地}

集落設定の悽子は第 1 四のごとくである。駅付近に居を定めたグループほ 1 戸当り 5 a の宅地割を計画的に施行し，いわ路村形態をとったのに対して北 持よび東辺部に入植したグループチ当時まだ開懇が点的にしか進んでいなかっ

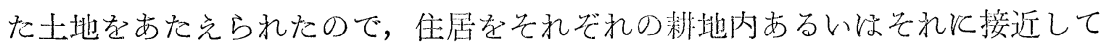
建てたため散居形態をとるにいたった。

住居建設と前後して1948年末から翌1949年汇かけて罚協の下で土地売渡しが 行われた。その際地目を耕地と付莦地（二新炭採草地）飞2 分し，当時までに開 拓が相当進んでいた中央部を除いた他の部分でも可耕地と目された所は耕地と して売り渡された。伀久甲州街道以西の部分は，8組合並立時には組合毎に分

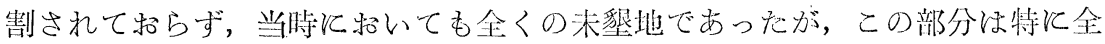

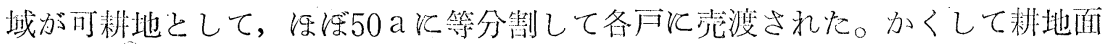

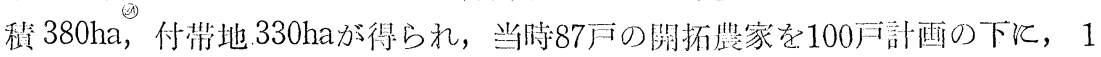
戸当り耕地 38ha，付带地3haをとれぞれあたえた。これにもとづいて開坆計画 がたてられたわけである。

かって入会地であった南辺部々戦後も旧入会部落に返されるととなく開拓用 地に組み入れられていたが，これを分㓶して開拓民に売却すること関係部落 を刺戟し，反目をかう恐れのあったととと，この時期にはまだ詳縕な踏查が行 われていなかったことから排水不良で不可耕地とみなされたことから，付带地 として付近開拓宠と旧入会部落是との共同用益飞李かされた。

以上のごとき集落設定と耕地配分の順序のため各 戸の所有地が錯围形態をとるルいたったことは当然

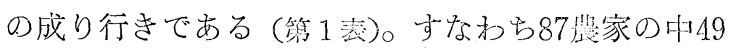

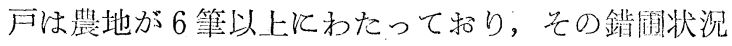
は一般の既存蜄村とほとんど差がないていてよい であろう。当開拓地の面程 (710ha) 加広いため耕地 への到達麻がいっとう大となるの浔然である。い

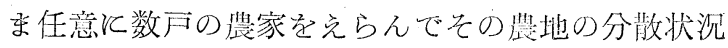

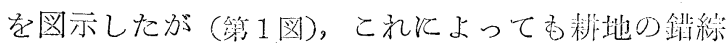
状洒の一端をうかがうことができよう。

箈 1 琵 集落分散前後 の葠地の分布状沉

\begin{tabular}{|c|c|c|}
\hline 1 F当り篗数 & 1952 & 1955 \\
\hline 1 & 1(戸) & $22($ 户) \\
\hline $2 \sim 3$ & 9 & 53 \\
\hline $4 \sim 5$ & 28 & 12 \\
\hline $6 \sim 7$ & 42 & \\
\hline $8 \sim 9$ & 7 & \\
\hline 部 & 87 & 87 \\
\hline
\end{tabular}

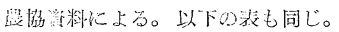

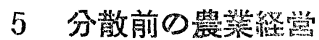


水田経営は㐎候的に望み得ないので開拓当初数年は自給作物としてはソバ・ ヒエ・ライ麦・大豆・ジャガイモ等が中心であった。蔬菜栽培が本格的にのび たのは1949年の野菜統制徹廃以後の ことである。初め大根・甘らんが中 心で後泊菜が加わっで。自給的基 盤の薄弱なかかる亩品作物のみの晨 莱経営ほ好。不沅飞一喜一嚳せざ るを得ない。例光ば1951年甘らん 5 貫入 1 箱の最高相場は 148円 60鈛で あったが最低相場は23円89銭であっ た。年によっても洒格に非常な差が あるのはもちろんで，1949年組合の 出荷野荣金額は約 500 万円であった ものが1950年には出荷量の增加にも かかわらず野菜洒格の暴落で半分の 259万円弱という具合で，農家経済 はまさ不安定の限りであり, 経営 はいちじるしく投機的な性格を屯た ざるを得なかった。な拎泠涼な気候 故, 端境期飞出荷することはいうま でもない。

1949年当時の土地利用状沉をみて みよう。耕地面積は計画では 380ha となっていたが同年までの䍒績々 140ha にすぎない。作物の自給用あ るいは換金用の区別は容易ではない が 1949 年頃には雑穀・豆類 (小豆を 除く)・いも類は自給用として栽培さ れたとすれば全作付け面積に対する 割合主自給作物57.4\% (80.4ha), 撸

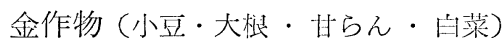
$27.1 \%$ (38.0ha), 飼料作物 (青刘えん 麦) $2.1 \%$ (3ha)である。自給作物が 過半を占めるがとの内容は第 2 表の

第 2 表 作物作付け面栍 (ha) と大家畜頭数の推移

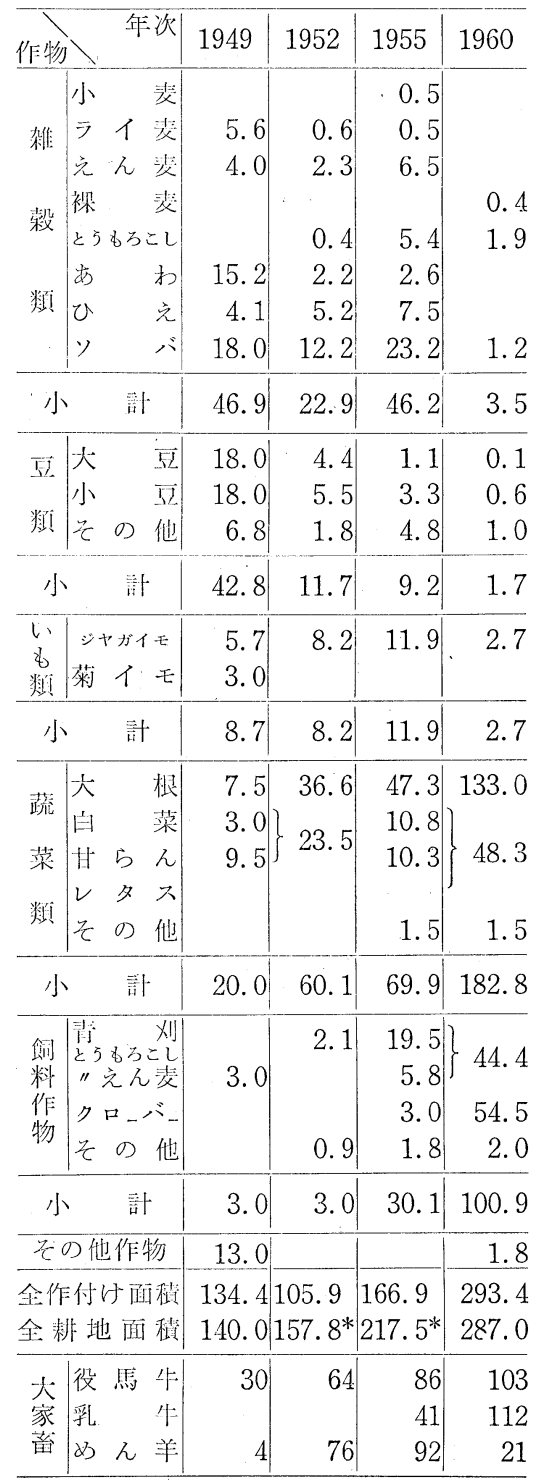

$*$ 開䛻面䄇 
ごとくで，これのみでは生活の維持は困難であったことは疑いなく，開拓民の 最大関心事は換金作物としての蔬菜の栽培であったことは当然で，彼等の現金 収入は伐採・薪の運搬・道路工事などによる日傭賃金を除けば全面的にこれに 依存していた。

1952年は開拓営農方針の变更・集落分散の寒施前年にあたるが，との土地利 用は自給作物 $35.3 \%$ (37.3ha)，換金作物 $61.8 \%$ (65.6ha)，飼料作物 $2.9 \%$ (3ha) で，1949年とは自給作物と換金作物の地位が転倒している。これは開拓初期の 自給食料確保の段階から一歩進しで自由遠郊式農業への段階飞達したことを意 味する。飼料作物には変化がみられない。これは第 2 表の家畜の欄をみれば当 然である。な特この間開懇はほとん ぞ進捗せず同年の 1 戸当り平均耕地 面積は 2ha とみたない。同年の農産 物販売高は第 3 表のごとくで蔬菜単 一栽培地域としての性格を如実に示 す。当時䩨菜収入以外現金収入の 途の全くない開拓民ととって，1戸 平均 20 万円前後の蔬菜販売代佰は 1 ケ年の生活費であり，営農費であっ て，これに全く依存していたといっ 第 3 表 各種澧深物䛀党高 (単位 1,000 开)

\begin{tabular}{|c|c|c|c|c|}
\hline & 年次 & 1952 & 1955 & 1960 \\
\hline 计 & 5 & 4,929 & 7,320 & 6,664 \\
\hline 白 & 菜 & 3,286 & 5,458 & 10,631 \\
\hline 泽 & 栈 & 913 & 2,773 & 8,651 \\
\hline \multirow{2}{*}{\multicolumn{2}{|c|}{ 大根・たく㟽ん }} & 7,858 & 23,579 & $10,729 *$ \\
\hline & & & 3,631 & 5,045 \\
\hline & 部 & 16,986 & 42,761 & 41,720 \\
\hline
\end{tabular}

*たくむんのみ てょい。

\section{6 集 落の 分 散}

a 動機 前記1950年の蔬菜相場の暴落は開拓民に大きな打撃をあたえた。 同年の彼等の窮乏は目を覆わせるものがあり，農協幹部をして営農方針の転換 を真剣に検討させるととになった。として蔬菜単一栽培の投機的不安定性から 脱却して農家経済安定性をもたせるとともに，あわせて蔬菜の連作にもとづ く消耗した地力を回復するには，かかる高冷地に怙いては畜産導入による混合 （同）農業方式をとる以外飞ないと，結論されるにいたった。収益の少なくと む 3 分の 1 を畜産から得て農家経済の基礎を固妪とた。営農方針の一大転

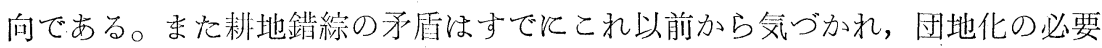
性は認められていたが，彼等は混合農業への切りか光と同時飞，これ飞必須な ものとして，との間題を一挙飞解決せんとした。

集居・鍇圑形態が社会生活上あるい㥩度の共同化の場合はともかくとして 個別経営下で忹営農上好ましくないことほいうまでもないが，わが国一般の水 田農村にあってはこれが不都合であることは認められていてもせいぜい区劃整 
理・耕地の集団化の段階ととどまっていて——これすら単に錯國是正だけの目 的で行われるのはまれで土地改良事業㳊随伴して行われるのが普通である—新しく配分を受けた耕地に向けて住居を移転までして営農上の利便を得んとす る例はまれである。区劃整理によって耕地が団地化はしたが住居からそれにい たる距離はむしろそれ以前より遠くなることがあってもな怙然りである。要す ると一般の水田農村で柱居から䉽地にいたる距離などはとれはど営農上真刻 な問題ではないのである。

ところが野辺山開拓地に招いては事情が異なる。ここでは 1 戸当り 3.8ha の 耕地々 3ha の付带地, あわせて 6.8ha の農地を所有, 経営して扣り, その面 積は北海道を除く内地農村の常識外である。この農地が錯綜し，住居がこれか ら遠距離にあることは営晨上屯ことに由々しき閏題である。例光げ第 1 図に示 した C 氏は耕地を 3 筆, 採草地を 3 筆所有しているが氏は小海線以南の畑に行 くには約 $1 \mathrm{~km}$ ・最奇りの耕地まででも約 $800 \mathrm{~m}$ ，佐久甲州街道以西のもつとも

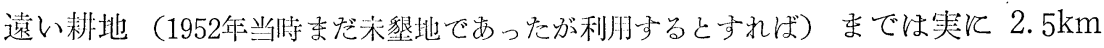
を要する。

一般飞農業経営の合理化を集落と耕地の関係の改善の面から行うには, 集落 立地を特汇制約する自然条件がない場合二つの方法が考えられる。一つは共同 化を前提飞集居・集围制の採用である。共同化を行うとは相互の連絡・共同施 設の設置飞集居制が望ましいからである。いま一つは個別経営の下に散居・集 圃制をとる方法である。この場合は農地への到達度の改善が眼目となる。いずれ としても集戋制が必要なととは両者に共通である。野辺山では後者を兄らんだ。

ところで高冷地野辺山に招いては, 個別経営の下では混合農業は蔬菜単一栽 培よりむいっそう散居・集围制を必要とする。すなわち畜産は牧草栽培を必須 とするが，刈りとった牧草は一方では蔬菜栽培に労働力を傾注せ齐ばならない 夏期に畜舎まで每日運搬せねげならない。さらに秋には短期間に，冬にそな光 てサイロ積みを行うが，家族労働力が一般飞少ない開拓民にとっては牧草地が 遠距離にあっては苦痛は大である。采た厩肥を遠距離の分散した耕地に運搬す ることは大きな労働力の消耗を伴う。広い䩨地の経営には畜力・機械力の使用 を不可欠とするが，鍇固制は作業能率をいちじるしく低下せしめる。

以上のごとき集落の分散・耕地の集団化を必要とする一般的条件に加兄て野 辺山開拓地にはこれを必須とする特殊な事情があった。前述の如く当初(1948 年) 1 戸当り 3.8ha の耕地の確保を計画していたが，1952年までと開墾・耕地 化されたのは 150ha で1戸当り 2ha に達せず，かかる小面積では畜産と商品 作物栽培の両方を営むには，このような高冷地では狭少にすぎて，抜本的な開 
墾の必要に迫られていたことである。佐久甲州街道以西 (120ha) を可耕地とし て分割・売渡しを行ったことは前に述べたが，ここは集落から遠距離にある上 に灌木が繁茂し，巨硫（直径60〜80 cm）が散在しているため，1952年にいたって

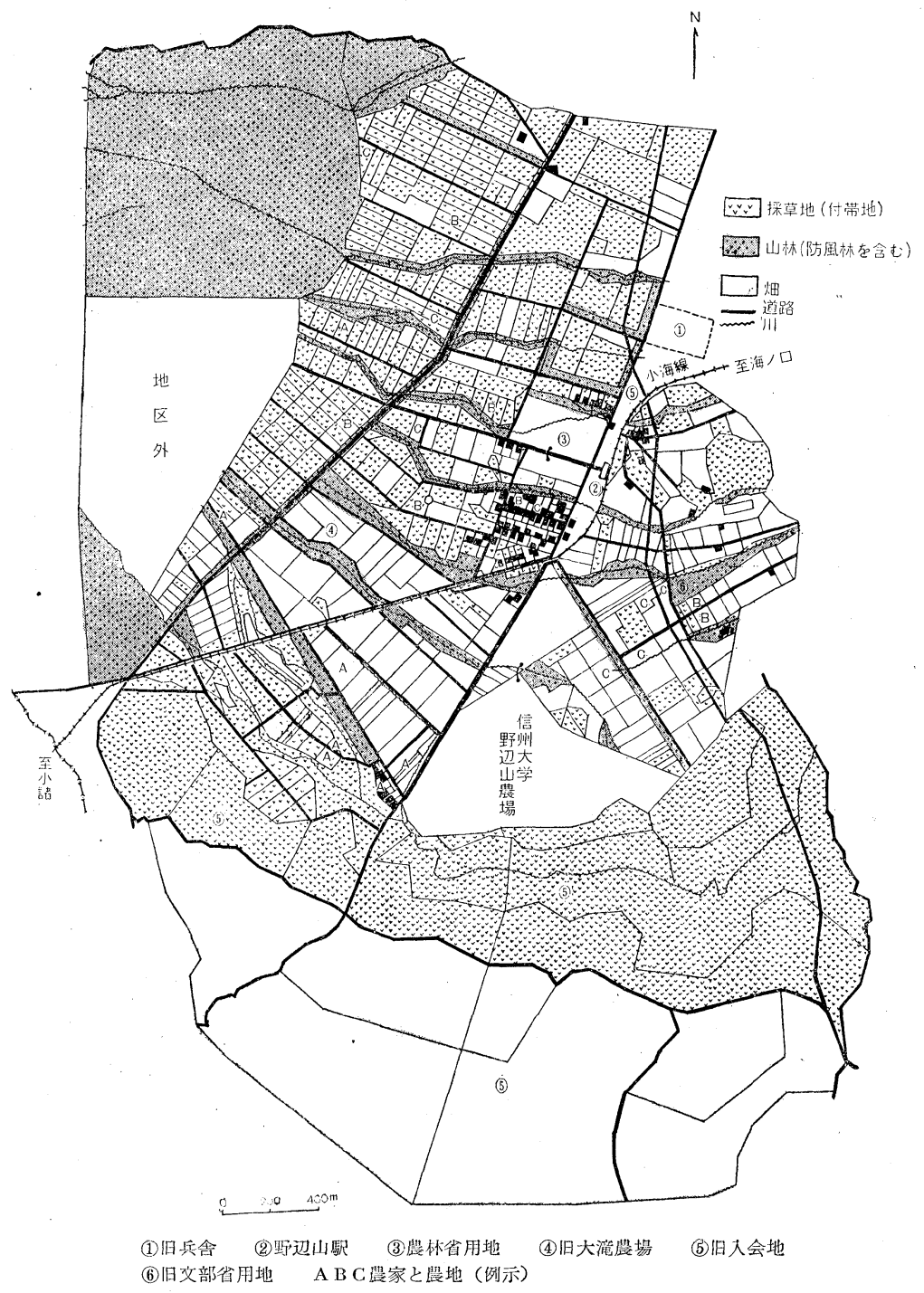

第 1 図 分散前の農地と集落*（1950年現在）

*「長野県野辺山の一地区, 開拓平面図」と「土地置収令書」による。 
も南辺を除きほとえど全く開墾が進まず，個人力では早急な開墾が困難である ことが判明した。その反面, 開拓地南部の付帯地とされていた旧入会地が草原 状を呈し土壤屯深く，機珹開墾の難易を左右する樹木，巨啋もまれにしかなく，

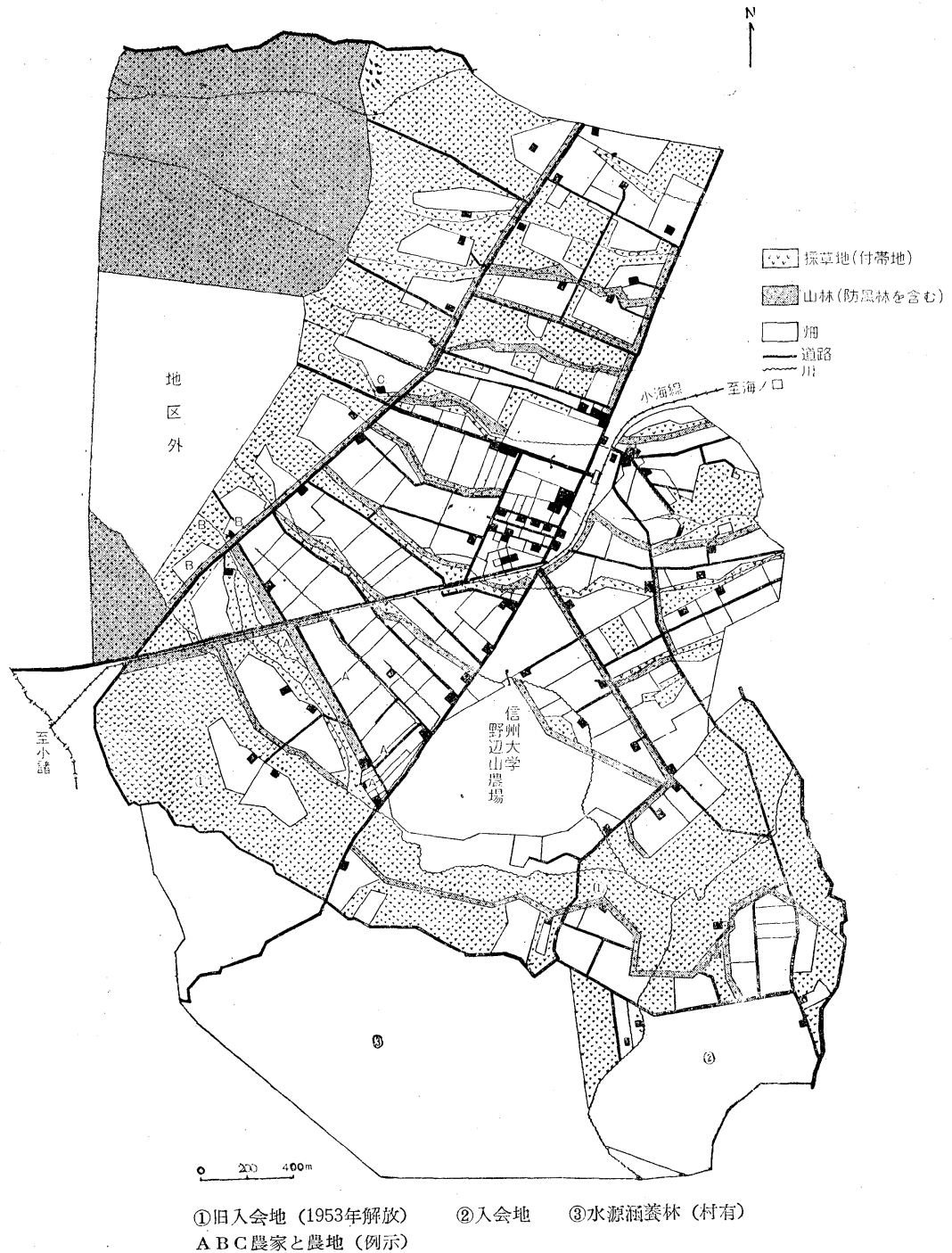

第 2 図分散後の農地之集落* (1960年現在)

*「長野県南佐公郡南牧村野辺山的一地区磼定図」に上万。野边山駅前

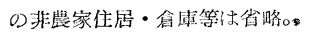


排水不良の点は排水溡の掘さくで容易飞解決され得ることから, 旧入会部落の 承認が得られさ方すれば，耕地として末ことに恰好の場所であることがわかっ て，前者を付带地，後者を耕地として開懇計画を変更した。そして組合幹部の 再三再四にわたる旧入会部落との交渉の結果，旧入会地の相当部分が開拓民に 完全飞解放された（第 2 図）。一部はな招水源涵㧔林，入会地として残されたわ けである。ところがこの解放された旧入会地は集居部から $2 \mathrm{~km}$ 近くも離れて いるので，住居を移転しない限り開懇しても耕作は不可能である。このことは 佐久甲州街道以北の一部の可邦地飞ついても同様であった。

分散計画の垁施を容易にしたものに農家経济の向上がある。電登の導入の便 宜が駅前に集落を密集させた一因であったことは先に述べたが1952年頃ねはと の魚担金を捻出する余裕が生じて拈り，縁辺部に移ってもランプ生活を余儀な くされることは考えられなかった。また家屋むかなり老朾化して打り，建てか 㿝必要な時期であった。閵拓地内では地下水位々 $4 \mathrm{~m}$ 前後で場所によっても ほとんど差がなかったことも分散を容易にした理由の一つである。以上の客観

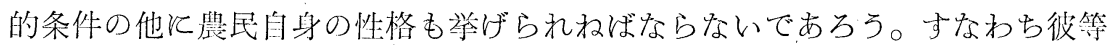
開拓民の大部分は従来の村落の伝統的な面を外国生活で一応清算したと考光ら れる上に，入植後の商品生産的農菜できわめて合理的・科学的性格をもつにい たり，これが営晨条件の改善，すなわち分敞計画に積極的飞応じる態度をとら せたようである。営農条件の改良と対する熱意は自給的基盤の薄弱な高冷地闒

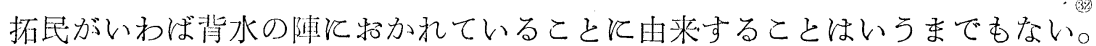

b 過程住居の移転・集落分散の計画が実施されたのは1953年になって からである。同年年頭の組合頤時総会に沶いて組合幹部は農地の交換分合・住 居移転・開墾計画蛒よび営農方針の変更を提議し，全会一致で施行が決議され た。耕地の集団化・集落の分散祝来の耕地の再区分・交换分合を必預とする が，これについては耕地が可及的に一団地となるように行われたことはもちろ えである。

住居移転については部落每に移転の必要な農家の有無・数を組合が提示し， 希望者を募る才法を用いた。移転農家の大部分は未墾地に入植するのであるか ら耕地の開墾括よび必要な農道の整備は組合が代行した。また移転資金として 組合から 4 万円が支給された上に，10万円が10ケ年無利息で融資された。移転 が必要とされたのは全農家87戸の中35戸でこの計画数は直ちに達せられ，これ らは1953－54の中に移転を完了した。移転が特に必要々されたのは駅前の密集 部であったことは，とれまでの集居の程度から推して当然であった。かくて集 落分散の結果は，その後個人的飞移枟した 8 戸を加古ると第 2 威のごとくであ 
って，農家の耕地和よび付带地が住居に漖しく接近したことは数戸の例示から も明らかであろう。耕地の集団化の様子は第 1 表のごとくである。

c 意 義 新しい開拓地の集落に散居形態をとるものが多いことは周知 の事実であり，同じ八ヶ岳西麓の南原山開拓地に括いても散居している。屯た 開拓地飞括いては初期の集落形態が変化しやすいことも知られている。

これらのことは当野辺山についても妥当する。たしかにここは新しい開拓地 であり，開拓当初の住居分布が後に不適当なことが認められるにいたって，住 居の再分布与なわち集落形態の変化を経駼した。しかしここで注月したいのは 住居の移転は単に外部的条件の变化に消極的飞順応せんがために行われたので はなく，前述の如く耕種農栄から混合農莱への転换に必須の条件として，ょり 積極的に計画されたものであるということである。この点在来の農莱経営形態 の下に耕境の拡大が行われ，それに伴って住居が移転したものや耕境の拡大に よらなくても住居と耕地の関係から住居の移転が行われたものと蛙異的であ るというべきである。

\section{7 分散後の農業経営}

学農方針の転換，集落分散計画実施後 3 年目の1955年，耕地面積は 218ha， 作付け面積 167haで1952年にくらべてそれぞれ31.5\%，57.8\% と坦加し，1955 〜1960年に注更にいっとうの增加をみたのは第 2 表の通りである。前者は機械 開墾による耕境の拡大，後者は飼料作物の增加にもとづく。飼料作物は 1949 , 1952の雨年共全作付㚈面積の3\%以下にすぎなかったが，1955年には18.0\%を 占めるにいたり，実面積にして10倍と飛躍的飞增加した。1955年頃に注小麦・ ソバを除く雑穀類は飼料に用いられたのであるから，これを加劣ると飼料作物 の地位は更に高くなり，全作付村面積の 3 分の 1 強を占めるに及几でいる。こ の割合は1960年には更に若干增している。一方疏菜の割合は1955年に41.8\%で 1952年の61.9\%より低下して招り，やや後退したかねみえたが1960年には62.3 \%で旧に復した。自給作物は1955年にはまだソバがあったが1960年には作付け 面積が減少して，自給作物は皆無に近い状態にいたっている。

混合農業への転換は農産物販売高の上からも認められる。すなわち第 3 表の ごとく転撸前の1952年に扮ける組合を通じての肘売高は甘らん・白菜・レタス ・たくあん・大根で全部占められ，牛乳先の他の畜産物によるものは皆無であ ったのに1955年には，畜産物販売高は約 360 万円で全販売高の $8 \%$ を占め，19 60年度には $14 \%$ をめるところ末で成長した。収益の 3 分の 1 を音産から得ん とする営農方針転換当初の計画の段階飞達するまでには，末だ相当の距離があ るが，混會農莱が軌道にのりつつあるといってよいであるう。 
現在 (1960年)，農家によって畜産導入の程度には相当の差がある。第 4 表に 示したようと音産粗収入が全粗収入の $10 \%$ 以上 の農家全農家の $45 \% ， 30 \%$ 以上の農家は $8 \%$ そすぎない。畜産粗収入皆無の農家が全農家の 3 分の 1 ああって，乙れからは必らずしも全面 的飞混合農業飞転換しつつあるとみ充ないか子 知れないが，乳牛を飼育していないのは87度家 中16戸 (1960年) 飞すぎないから率産収入の增加 は時間の問題だと考えでい。

な和䜋解をさけるためと, 分散後の以上のご とき農業経営の変容は分散によってもたらされ たと筆者は主張しているのではないととを付言

節 4 表 崖应粗收入の全粗收 入に対与る割合別農家数 (1960年)

\begin{tabular}{|c|c|}
\hline 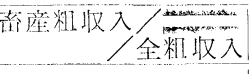 & 想家传数 \\
\hline 0 & 29 \\
\hline 10\%以下 & 19 \\
\hline $10 \sim 20 \%$ & 19 \\
\hline $20 \sim 30 \%$ & 13 \\
\hline $30 \sim 40 \%$ & 5 \\
\hline $40 \%$ 以上 & 2 \\
\hline 計 & 87 \\
\hline
\end{tabular}

して括く。混合農業はかかる高冷地でほ採用さるべき農業形態であると考克ら れ，そのために分散が必要とされ，実施されたのであって，分散は混合農策経

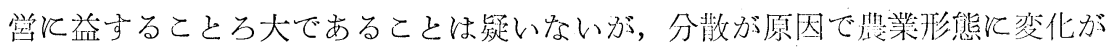
起きたのではなく，分散はいわば結果である。

\section{8 分散による新たな問題}

集落の分散以混合農業経営にきわめて有意義であったと教光られるが，分散 によってもたらされたマイナスの面はどうであろうか。見聞によって知り得た 主要なむのを列举すれれば，むず第一に周辺飞移転した農家は日常生活のいわば センターである農協と駅招よびその付近の店舗から遠くなったととである。ま た牛乳は毎朝農協北隣の集乳所まで運搬せねない。第 2 は弟の通学が 不便になったことである。小学校は隣部落「板橋」との中間に，中学校は「海 ノ口」とあるが，周辺部の農家からは片道 1 時間半を要する。第 3 は通信の不 便な点で，農家と農協との連絡はもとより，農家相互間の連絡・交際を密纣 るのは容易でない。特に冬飞とうである。但しこれは近く各戸飞電話を設ける

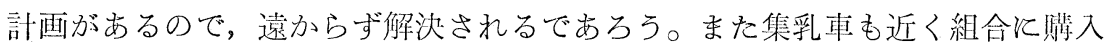
される計画なので，勿:朝の牛乳の運搬は不必要となるう。

以上の主として社会生活上のマイナスの面はあっても, 営㻃上のマイナスは 現在のところ考兄られない。農業協同化あるいは高度の機械化（わが国ではこれ

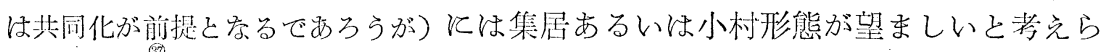

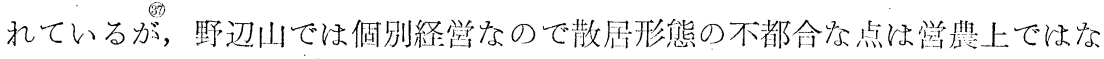
い。

\section{9 あとがき}


再言するまでもなく，野辺山に括けるがごとき動機をもって農村集落の形態

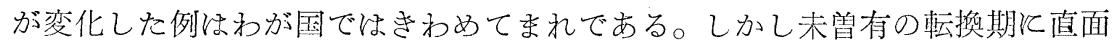
するわが国農業の進路の一つが混合農業であるとするならぼ，当開拓地が第二 次大戦後の高冷開拓地という特殊な社会的物よび自然的条件下年るとはい光， 今後の農村計画，就中農村集落計画に一つのモデルを提供しているかと考兄ら れる。農業協同化を推進するとは，集居が一般的なわが国の農村飞あっては鉆 固形態の是正だけでよいが，個別経栄下ではその上潵居制への転換が必要で あろう。

また野辺山の例は開拓・農学干拓地飞扮ける集落計画の重要性を認識させる。

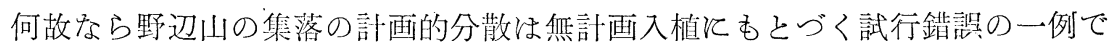
あるからである。莫大な費用と労力を投じてなされた開拓・農業干拓地に招い

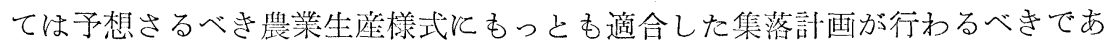
る。そのためには，従来各地に行われてきた集落計画の適否が検討されねね゙な らない。

本報告飞あたって広自大学地理学教室の諸先生の日頃の御指導飞感謝する。 西村嘉助先生には1959年度科研費の一部を本研究にさいていただいた。調査に

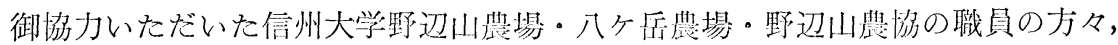
開拓農家の方々飞御礼申し上げる。

\section{【註】}

(1) 西川治; 莀村集落の人文生態学的研 宛, 東京大学地理学研究 3 , 1954。

(2) 谷岡武雄; 集落の二次的分散, 立命 館文学 9,1953 。

(3) 同氏；ハンガリー・アルフェルドに 於ける賑村集落の進化について，立命 館文学 $89 ， 1952$ 。

(4) 拙稿; 山地集落の移陲, 芸倩地方必 研究34，1960，ではこれを混同主る愦 りがあった。

(5) 綿貫学彦; 黑部扇状地の計画的集村, 地理教育, 聚落地理学涂文集, 1935 。

(6) 小寺麻吉・岸本英夫; 大井川下流の 散居制村落，地洋15の 9，10，1932。

(7) 高田正规；梵島湾于拓地，地理 6 の 3,1961 。

(8) 竹内常行; 黑部川扇状地の聚落形熊 に閵する二，三の考察，地詐 8 の 2 , 1932 。

(9) 長井政太郎; 散村の発達特に鬼面川 扇状地の埸合, 川形大学紀要 (人文)
2,1952 。

(10)菊地利夫氏（九十九里浜に抒ける臨 海:集落の発達の歴史地理学的研究, 人 文地理11の 6，1959）がこの区別の必恶 性を述べられた。

(11) Demangeon A; Problèmes de géographie humaine, 1952. p. 195.

(12)市川健夫氏が関説されたことがある。 氏は野辺山の 2 地区の住民(10戸)も含 めて述べられたが，本稿では野辺山の 1 地区の及を报っている。同氏; 高冷 地灌䍴の発展段階と今後の展望, 地理 5 の 7,1960 。

(13) 米全二郎; 東亚の集落(古今嗇院), 1960, p. 129 。

(14)山口源吾; 裾野型高冷地八ヶ质山棍 の開拓景, 地理 5 の 7,1960。

(15) 以下の気候関係の数値は全て, 信州 大学野辺山農場; 高冷地作物試験研究 結果の概要, 1961, による。

(16) 山崎不二夫; 晨地造成（全原川版怢 式会社), 1958, p. 18。 
(17) 5 年平均積曷量(最深)は $26.2 \mathrm{~cm}$ 。

(18) 本岡武; 農地開拓論（技術資料刊行 会) 1948 , p. 77 。

(19)伐採しただけで拔根までは行わなか った。

(20) 野辺山開拓農業協同組合; 野辺山開 拓振興対策事業報告書(謄写)，1956。

(21)䋑辺部の集落では電燈導入は当初か ら期街できなかった。これも政腐形態 をとらせた理由の一つである。

(22) 駅前は農林省用地として開拓民に解 放されなかった。

(23) 営费資金の融資・生産物の肘売以全 て農協を通でて行われる。

(24) 1952年 9 月現在の奏祭の耕地面積は 150ha にすぎない。

(25)駅前の狄長な入会地は入会部落に返 却された。

(26) 福田邦三他; 睅辺山高原開拓部落の 実態調查，民族衛生，19の34，1953。

(27) 農協による営農指導は農家に対して 強制力こそもた欢が影響力は大きい。

(28) 松井武敏; 現代地理謨座; 第 4 巻, 都市と村落の地理（河出㬩房）1957, p. 34 。

(29) 水津一朗; 集落地理講座旌 1 巻（朝 倉䡒店)，1957，p.342。
(30) 白井義彦氏の御教示による。

(31) 建築者安るいは土木学者は個別経営 下に拈いても集厓制が望ましいと考兄 ているよ5である。川名吉衛門; 集落 地理譵座第 1 巻，村落計画。

(32) 千葉德爾; 山間高冷地の土地利用方 向, 地理 2 の11, 1957。

(33)地剕が概して南北方向にのびている のは等高線に従っているためである。 作付以も卧之えどこのJ向に行われて いる。もちろん土壌流将をさけるため である。

(34) 谷岡武雄; 日本に於ける散扂集落の 特質 - 第一報, 立命館文学, $70 \sim 72$, 1949。

(35) 能登志雄; 聚落の地理 (古今留院), 1952 , p. 80 。

(36)自給的農桇から商業的農莱への転換 によって, 開拓初期の計画的集村から 散愿形熊に移行した例はカナダに持い てもみられる。但しこれは然計画に行 われたものである。 Warkentin J; Mennonite Agricultural Settlements of South Manitoba, Geogr. Rev., July, 1959 .

(37) 前掍 (16) p. 165 。

(広帛大学大学院学生)

\section{Dispersion Movement of the Settlement in Nobeyama} by Setsuo OGASAWARA

After the end of the World War II about 100 repatriates settled here on 710 hectares area. Because there were no other cultivated lands around and they were already in groups, they founded here an agglomerated settlement around Nobeyama Station (see fig. 1), which also enabled them to cut down the cost of electric insta1lation.

They raised exclusively vegetables, i. e. chinese cabbage, cabbage, radish, etc. But such monoculture was unstable at times of depression. So their leaders decided to adopt the mixed-culture of vegetable raising and stockbreeding instead. To realize it, it was necessary to remove some farmhouses to the environments to shorten the distance between home and field. Thus the agglometated settlement has changed into a dispersed settlement (see fig. 2), which uncommon in Japan except in Hokkaido. 